\author{
Journal of Sustainability Business Research (JSBR) \\ Vol-1,Issue-1,Desember (JSBR) \\ E-ISSN: 2746-8607 \\ http://jurnal.unipasby.ac.id/index.php/jsbr
}

\title{
PENGARUH LEVERAGE DAN LIKUIDITAS TERHADAP KONSERVATISME AKUNTANSI PADA PERUSAHAAN ROKOK TBK YANG TERDAFTAR DI BURSA EFEK INDONESIA PERIODE 2013-2018
}

\author{
Sofi Sani Safitri1, Sigit Prihanto Utomo., 2 \\ Universitas PGRI Adi Buana Surabaya ${ }^{1,}$ \\ sanisafitris@gmail.com
}

\begin{abstract}
This study aims to test the effects of leverage and liquidity on accounting conservatism, this research uses secondary data. Sample of this research is cigarette company from the Indonesian Stock Exchange in 2013-2018. Samples were collected by using purposive sampling method and resulting two companies to be the samples. The observations using descriptive statistic, a test of classical assumption, and multiple regression analysis. This study conclused that independent leverage variabel and liquidity has simultaneously effect to accounting conservatism, and leverage hasn't effect significantly to accounting conservatism.
\end{abstract}

Keyword: accounting conservatism, leverage,liquidity

\section{PENDAHULUAN}

Perkembangan dalam dunia usaha semakin pesat hingga memicu persaingan antar pelaku bisnis. Perusahaan dituntut untuk bersaing demi mempertahakan bisnisnya, salah satu wujud mempertahankan diri yaitu dengan mengontrol laporan keuangan perusahaan. laporan keunagan ialah bentuk dari penyajian informasi yang digunakan untuk menilai kondisi perusahaan, baik untuk pihak internal maupun eksternal. Untuk mewujudkan informasi laba yang berkualitas maka prinsip akuntansi harus menciptakan angka yang signifikan dan kredibel.

Prinsip konservatisme ialah suatu prinsip yang harus dipakai untuk sebuah pelaporan keuangan oleh perusahaan sebagai repson dalam menghadapi suatu kondisi yang tidak pasti dimasa mendatang. Prinsip konservatisme ialah prinsip kehati-hatian pada suatu keadaan dengan tujuan menghindari optimism yang berlebihan dari pihak perusahaan. (ghozali dan chariri 2007, dalam Angga Alfian 2013) konservatisme akuntansi harus segara menerima adanya rugi, utang ataupun biaya yag bakal terjadi dan tidak boleh menerima margin, atau pendapatan sebelum terjadi.

Perusahaan yang menerapkan prinsip konservatisme akan membentuk nilai pendapatan serta asset perusahaan yang rendah,namun nilai biayanya cenderung tinggi yang berakibat pada laporan keuangan yang disusun akan membentuk jumlah laba yang rendah dikarenakan prinsip konservatisme ini ialah prinsip yang memperlambat pengakuan margin, tetapi mempercepat pengakuan beban. Standar akuntansi keuangan mengungkapkan ada beragam kaidah yang mempergunakan prinsip konservatisme, yakni PSAK no.14 yakni persediaan yang berhubungan dengan penetapan perhitungan beban persediaan, kemudian PSAK no.16 aktiva tetap serta 


\section{Journal of Sustainability Business Research (JSBR) \\ Vol-1,Issue-1,Desember (JSBR) \\ E-ISSN: 2746-8607}

http://jurnal.unipasby.ac.id/index.php/jsbr

penyusutan, PSAK no.19 yakni aktiva tak berwujud yang bersinggungan dengan amortisasi, dan PSAK no.20 yaitu beban riset serta pengembangan.

Fenomena yang terjadi berkaitan dengan kurangnya memperhatikan prinsip konservatisme akuntansi pada sektor pertambangan yaitu PT Timah Tbk, Ikatan Karyawan Timah melakukan unjuk rasa didepan kementrian BUMN untuk menuntut direksi PT. Timah Tbk mundur karena sudah banyak membuat kesalahan serta kelalaian dalam masa memimpin selama tiga periode dari tahun 2013 dengan melakukan suatu kebohongan public lewat media, seperti pada publikasi laporan keuangan periode satu tahun 2015 menyatakan ketepatan dan rencana yang berbuah prestasi yang baik padahal saat itu laba operasi telah rugi sejumlah Rp. 59 miliar. Disisi lain penururnan margin, PT Timah pun menatat adanya penambahan utang hamper 100\% sibandingkan 2013. Pada saat 2013 utangnya hanya mencapai Rp. 263 miliar. Pada tahun 2015 ada penambahan utang hingga berjumlah 2,3. kegiatan pemalsuan pelaporan ini sengaja untuk menutupi kemampuan keuangan PT Timah yang tidak baik. Kepala Ikatan Karyawan Timah mengatakan bahwa sejak tiga tahun perusahaan mengalami kondisi keuangan yang tak baik, dimana ketidaksanggupan jajaran direksi PT Timah keluar dari perangkap kerugian yang berakibat $80 \%$ wilayah tambang PT Timah dialihkan kepada rekan usaha. Dapat kita ketahui bahwa perusahaan tersebut tidak memperhatikan prinsip konservatisme, yang melakukan kekeliruan atas pencatatan laporan keuangan, padahal prinsip konservatisme ialah prinsip yang meyakini kehati-hatian dalam mencatat margin,beban, laba maupun rugi. Dalam pelaporan keuangan membutuhkan konservatisme untuk mengakui serta mengukur aktiva dan profit dengan cara hati-hati kaena kegiatan ekonomi dan bisnis dikelilingi sesuatu yang tak pasti.

Prinsip konservatisme hingga saat ini masih banyak mengalami banyak pertentangan, contoh pertentangan yang kerap terlihat ialah prinsip konservatrisme ini berdampak pada hasil dan laporan keuangan. Indrayanti (2010) mengatakan konservatisme bisa menjadi kendala yang berpengaruh terhadap laporan keuangan, bila cara yang dipakai sesuai dengan prinsip akunansi yang konservatif maka hasilnya akan cenderung bias dna tak menggambarkan fakta. Tetapi dipihak lain konservatisme akuntansi dianggap akan menciptakan margin yang baik karena prinsip tersebut menghambat perusahaan menjalankan aktivitas melebihkan margin serta memudahkan pemakai laporan keuangan dengan laba dan asset yang tidak melebih-lebihkan (overstate).

Ada beberapa aspek yang bisa berpengaruh terhadap konservatisme akuntansi yakni : Leverage menampilkan berapa besar asset yang dipakai untuk aktivitas operasional perusahaan dibebani oleh utang serta menggambarkan keamanan yang diberikan kreditor. Leverage dipakai untuk memperkirakan kondisi perusahaan dalam membayar kewajiban jangka Panjang.(Lo, 2005 dalam Jesicca salim 2018) membuktikan apabila perusahaan memiliki utang yang besar maka kreditor pun memiliki hak mengatahui dan memperhatikan jalannya operasional perusahaan tersebut. Karenanya, kreditor berharap pada perusahaan untuk mempraktikan prinsip konservatisme akuntansi dalam laporan keuangan sehingga kreditor benar-benar percaya dengan keamanan dan pengambilan dananya. Berarti bila tingkat leverage pada perusahaan semakin tinggi, maka hak para kreditor untuk mengetahui dan ikut mengawasi jalannya kegiatan operasional perusahaan adalah semakin besar.

Faktor kedua ialah likuiditas. Likuiditas ialah indicator berkaitan dengan kesanggupan perusahaan melunasi seluruh utang finansial jangka pendeknya pada saat habis masanya dengan memakai asset lancer yang tersedia. Jika likuiditas perusahaan sehat maka pimpinan akan lebih berhati-hati 


\section{Journal of Sustainability Business Research (JSBR) \\ Vol-1,Issue-1,Desember (JSBR) \\ E-ISSN: 2746-8607}

http://jurnal.unipasby.ac.id/index.php/jsbr

untuk membuat laporan keuangan dengan prinsip konservatisme. Kondisi keuangan yang kredibel membuat beban politik yang melekat pada perusahaan akan makin besar.

Dengan berbagai dasar diatas, peneliti tergiring untuk melakukan observasi tentang Pengaruh Leverage dan Likuiditas Terhadap Konservatisme Akuntansi Pada Perusahaan Rokok yang Terdaftar di Bursa Efek Indonesia Periode 2013-2018. Adapun rumusan masalah sebagai berikut :

1. Adakah leverage serta likuiditas secara simultan berpengaruh terhadap konservatisme akuntansi pada Perusahaan Rokok Tbk tahun 2013-2018.

2. Adakah leverage dan likuiditas secara parsial berpengaruh positif terhadap konservatisme akuntansi pada Perusahaan Rokok Tbk tahun 2013-2018.

\section{TINJAUAN PUSTAKA DAN HIPOTESIS}

Adapun penelitian terdahulu yang dijadikan sebagai acuan dan rujukan untuk melengkapi landasan teori, penelitian mengenai konservatisme akuntasi sudah banyak diuji dengan memakai variabel lain. Sebagai contoh : Penelitian yang dilakukan oleh Dini Firmasari (2016) berjudul "pengaruh leverage,ukuran perusahaan,financial distress terhadap konservatisme akuntansi", hasilnya yakni leverage terbukti ada pengaruh negative tetapi tidak signifikan terhadap koefisien dan financial distress berpengaruh negative dan signifikan terhadap konservatisme akuntansi. jesicca salim (2018) meneliti "analisis pengaruh intensitas modal, likuiditas, dan leverage terhadap konservatisme akuntansi", hasilnya menunjukkan bahwa intensitas modal berpengaruh negative terhadap konservatisme akuntansi,likuiditas dan leverage secara positif tidak berpengaruh terhadap konservatisme akuntansi. asmaul Khusna (2018) meneliti "pengaruh kepemilikan manajerial, leverage dan financial distress terhadap konservatisme akuntansi", hasil penelitian menunjukkan terdapat pengauh kepemilikan manajerial secara signifikan terhadap konservatisme akuntansi, leverage memiliki pengaruh signifikan negative dan tidak signifikan terhadap konservatisme akuntansi, sedangkan financial distress secara signifikan mempengaruhi konservatisme akuntansi.

\section{Landasan Teori}

(Basu (1997) dalam Maria Maya 2013) konservatisme akuntansi ialah kecenderungan akuntan dalam menggunakan tingkat verifikasi yang lebih tinggi dalam mengakui laba daripada rugi, hal ini berarti bahwa semakin tinggi perbedaan tingkat verifikasi antara laba dan rugi suatu perusahaan maka akan semakin konservatif pula laporan keuangan yang akan dihasilkan. Cara pengukuran konservatisme akuntansi ialah akrual total dikurangi arus kas aktivitas operasi. Berikut adalah model untuk mengukur konservatisme akuntansi yang dikembangkan oleh penelitian Givoly dan Hyan (2002) dan Zhang (2007) :

$$
\begin{gathered}
\text { CONNACCit }= \\
{[(\mathrm{NI}+(\mathrm{BP}-\mathrm{CFO}) / \mathrm{TA})] \times(-1)}
\end{gathered}
$$

Kasmir (2016:151)leverage ialah rasio yang dipakai untuk menakar seberapa besar aktiva perusahaan dibebani dengan hutang. Leverage juga bisa dikatakan sebagai pemakaian asset dan sumber dana perusahaan yang mempunyai beban tetap dengan harapan bisa meningkatkan laba pemegang saham. Perusahaan yang memakai leverage dengan tujuan supaya untung yang 


\section{Journal of Sustainability Business Research (JSBR) \\ Vol-1,Issue-1,Desember (JSBR) \\ E-ISSN: 2746-8607 \\ http://jurnal.unipasby.ac.id/index.php/jsbr}

didapat lebih besar dari fixed asset . Pengukuran leverage yang dipakai Debt to Asset Ratio, hal ini diyakini bisa memberikan informasi mengenai jumlah hutang yang dipakai untuk membiayai aktiva yang dipakai perusahaan untuk menjalankan kegiatan operasionalnya.

$$
=\longleftarrow .100 \%
$$

Van Horne dan Wachowicz (2012:205) Rasio likuiditas digunakan untuk menakar kapasitas suatu perusahaan untuk memenuhi kewajiban jangka pendeknya. Dalam penelitian ini dasar pengukuran likuiditas menggunakan Rasio Lancar (Current Ratio) yakni perbandingan antara total aktiva lancar dengan kewajiban lancer

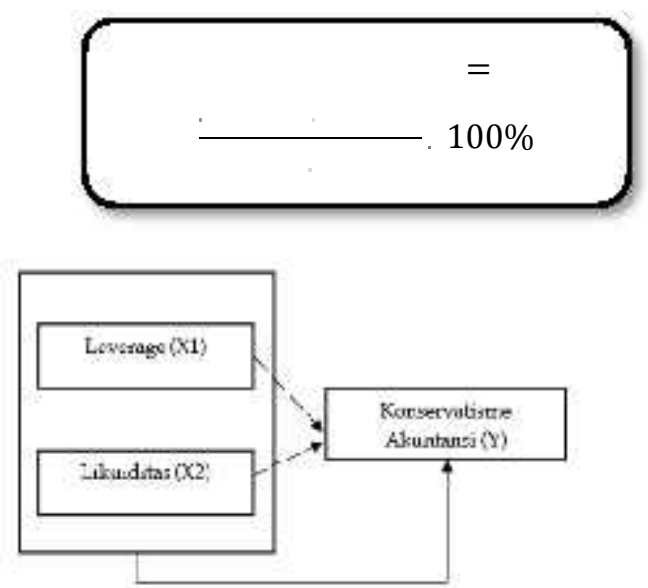

Gambar 1. Kerangka konseptual

\section{Hipotesis}

Berdasar pada kajian teoritis dalam penelitian terdahulu maka hipotesis ini meliputi :

H1 : Leverage dan likuiditas secara Bersama-sama berpengaruh terhadap konservatisme akuntansi.

H2 : Leverage dan likuiditas secara parsial berpengaruh positif terhadap konservatisme akuntansi.

\section{METODE}

Metode yang dipakai ialah pendekatan kuantitatif. Populasinya adalah perusahaan rokok pada bursa efek Indonesia periode 2013-2018. Sampelnya terdapat dua perusahaan rokok yang memenuhi kriteria, metodenya dengan teknik purposive sampling. Teknik pengumpulan data yang dipakai menggunakan metode dokumentasi berupa laporan tahunan perusahaan rokok pada Bursa Efek Indonesia periode 2013-2018. Teknik analisis datan ialah analisis regresi linier berganda. 
Journal of Sustainability Business Research (JSBR)

Vol-1,Issue-1,Desember (JSBR)

E-ISSN: 2746-8607

http://jurnal.unipasby.ac.id/index.php/jsbr

HASIL DAN PEMBAHASAN

1. Statistik Deskriptif

Tabel 1

Uji statistic deskriptif

\begin{tabular}{|c|c|c|c|c|c|}
\hline & N & A. Ahinum & Masimm & wean & $\begin{array}{c}\text { sd. } \\
\text { nevathn }\end{array}$ \\
\hline$x_{1}$ & 12 & 16 & 52 & $349 B$ & n\$8? \\
\hline \multirow[t]{3}{*}{ 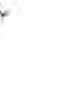 } & & - & - & - & 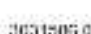 \\
\hline & 12 & $196 \div 250$ & 4383932.1 & 9226922.5 & 3615000 \\
\hline & & 590 & 9 & r4e3 & 2012 \\
\hline$x_{2}$ & 12 & 1,39 & 497 & 2.4803 & 122994 \\
\hline Valian & 12 & & & & \\
\hline nosture: & & & & & \\
\hline
\end{tabular}

Variabel konservatisme akuntansi ditunjukkan nilai minimum sebesar $-13629250,690$, nilai maksimum -4383932,119. Nilai range --9025922.87483. variabel leverage mempunyai nilai minimum 0,16 nilai maksimumnya 0,52 , nilai range 0,11872 . Variabel likuiditas mempunyai nilai minimumnya 1,39 , nilai maksimumnya 4,97 , nilai rata-rata 1,22994 .

\section{Koefisien Determinasi}

Tabel. 2

Koefisien Determinasi

\begin{tabular}{|c|c|c|c|c|c|}
\hline \multicolumn{6}{|c|}{ Model Summarye } \\
\hline Model & $\mathbf{R}$ & $\underset{\text { Square }}{\mathbf{R}}$ & $\begin{array}{c}\text { Adjusted } \\
\mathrm{R} \\
\text { square }\end{array}$ & $\begin{array}{l}\text { Std. } \\
\text { Error of } \\
\text { the } \\
\text { Estimate }\end{array}$ & $\begin{array}{l}\text { Durbin- } \\
\text { Watsan }\end{array}$ \\
\hline 1 & 703 & 0,494 & 0,391 & 2394346 & 1,076 \\
\hline
\end{tabular}

Nilai koefisien determinasi pada $\mathrm{R}$ square ialah 0,494 atau $49,4 \%$ dimana menjelaskan bahwa $49,4 \%$ dari konservatisme akuntansi bisa dipengaruhi oleh kedua variabel dependen terhadap variabel independent, dan 50,6\% dijelaskan oleh variabel lain diluar model penelitian.

\section{Uji F}

Tabel. 3

Uji $F$

\begin{tabular}{lccc}
\hline Model & Df & F & Sig. \\
\hline Regression & 2 & 4,391 & .047 \\
Residual & 9 & & \\
Total & 11 & & \\
\hline
\end{tabular}

Nilai Fhitung seb 4,391 > Ftabel 3,8853 dan Pvalue $<0,05$ 
Journal of Sustainability Business Research (JSBR)

Vol-1,Issue-1,Desember (JSBR)

E-ISSN: 2746-8607

http://jurnal.unipasby.ac.id/index.php/jsbr

4. Uji t

Tabel. 4

Uji t

\begin{tabular}{|c|c|c|c|}
\hline Model & & $\mathbf{T}$ & Sig. \\
\hline \multirow{3}{*}{1} & (Cunslant) & 0,417 & 0,686 \\
\hline & $\mathrm{x} 1$ & $-0,921$ & 0,351 \\
\hline & $x_{2}$ & $-1,833$ & 0,1 \\
\hline
\end{tabular}

Leverage mempunyai nilai thitung sebesar $-0,921<2,920$ dengan tingkat signifikan 0,381> 0,05 . Likuiditas memiliki thitung sebesar-1,833 $<2,920$ dengan tingkat signifikan 0,100 $>0,05$.

\section{Uji Normalitas}

Tabel. 5

Uji Normalitas

\begin{tabular}{cccc}
\hline Yariabel & $\begin{array}{c}\text { Asymp,Sig: (2- } \\
\text { talled }\end{array}$ & Kriteria & Keterangan \\
Residual & 0,200 & 0,03 & Nourual \\
\hline
\end{tabular}

Berdasarkan uji tersebut menunjukkan bahwa uji model regresi berdistribusi secara normal, dimana nilai asymp. Sig adalah 0,2 yang berarti nilai tersebut sudah melebihi ketentuan pengambilan keputusan secara probablitias yakni 0,05dan data layak untuk digunakan.

6. Uji multikolinearitas

Tabel 6

Uji Multikolinieritas

\begin{tabular}{|c|c|c|c|}
\hline \multirow{2}{*}{ Model } & & \multicolumn{2}{|c|}{$\begin{array}{c}\text { Collinearity } \\
\text { Statistics }\end{array}$} \\
\hline & & Tolerance & VIF \\
\hline & (Constant) & & \\
\hline \multirow[t]{2}{*}{1} & $\mathrm{x} 1$ & 0,118 & 8,464 \\
\hline & $\mathrm{X} 2$ & 0,118 & 8,464 \\
\hline
\end{tabular}

besarnya angka VIF pada variabel independent menunjukkan nilai $\leq 10$ dan pada nilai tolerance $\leq 0,1$.

7. Uji Autokorelasi

Tabel. 7

Uji Autokorelasi

\begin{tabular}{|c|c|c|c|}
\hline Yariabel & $\begin{array}{l}\text { Asumesia } \\
\text { (2,taifede }\end{array}$ & Soriteria & Keleringax \\
\hline Residual & 0,2356 & $P>0, \mu$ & $\begin{array}{l}\text { Tidak terisdi } \\
\text { sutokorclasi }\end{array}$ \\
\hline
\end{tabular}




\section{Journal of Sustainability Business Research (JSBR) \\ Vol-1,Issue-1,Desember (JSBR) \\ E-ISSN: 2746-8607 \\ http://jurnal.unipasby.ac.id/index.php/jsbr}

Uji diatas menunjukkan nilai asymp. Sig sebesar 0,130 yakni lebih besar dari nilai signifikan 0,05. kesimpulannya dalam uji regresi ini tidak terjadi autokorelasi.

\section{Uji Heteroskedastisitas}

Tabel. 8

Uji Heteroskedastisitas

\begin{tabular}{rlrr}
\hline \multirow{2}{*}{ Model } & & $\mathrm{t}$ & \multicolumn{1}{l}{ sig } \\
& & & \\
\hline & (Constant) & $-1,139$ & 0,284 \\
1 & Leverage & 1,363 & 0,206 \\
& Likuiditas. & 1,729 & 0,118 \\
\hline
\end{tabular}

Nilai sig yang lebih dari 0,05 pada kedua variabel independent, uji tersebut telah membuktikan bahwa data ini telah lolos dari uji heteroskedastisitas.

\section{Regresi Linier Berganda}

Tabel. 9

Uji Regresi Linier Berganda

\begin{tabular}{ccc}
\hline \multirow{2}{*}{ Model } & \multicolumn{2}{c}{ Unstandardized Coemicients } \\
& B & Std Error \\
\hline (Constant) & 4230599 & 10136899 \\
$1 \quad X 1$ & -16216308 & 17616412 \\
$X_{2}$ & -3115902 & 1700154 \\
\hline
\end{tabular}

Nilai konstanta sejumlah 4230598,805 yang berarti bila variabel independent bernilai 0 , konservatisme akuntansi sejumlah 4230598,805. Leverage memiliki nilai koefisien regresi sebesar 16216308,077. Terjadi kenaikan $1 \%$ pada variabel leverage, maka conservatism akuntansi akan mendapati pengurangan sejumlah 16216308,077 dengan syarat variabel lain konstan.Likuiditas memiliki nilai koef.regresi sejumlah $-3115901,734$. Terjadi kenaikan $1 \%$ pada variabel leverage maka konservatisme akuntansi akan mendapati penurunan sejumlah 3115901,734 dengan syarat variabel lain tetap.

\section{SIMPULAN}

\section{Pengaruh Leverage dan Likuiditas terhadap konservatisme akuntansi}

Pada hasil uji hipotesis pertama $(\mathrm{H} 1)$ dengan memakai uji $F$, didapatkan nilai Fhitung sejumlah 4,391 dan probabilitas signifikansi (pvalue) sebesar 0,047 atau 4,7\%. Dapat diketahui $p$-value dibawah tingkat signifikansi (a) 0,05 atau 5\%. Oleh karenanya hipotesis pertama diterima, atau variabel independent berpengaruh secara simultan terhadap konservatisme akuntansi pada perusahaan rokok Tbk. 


\author{
Journal of Sustainability Business Research (JSBR) \\ Vol-1,Issue-1,Desember (JSBR) \\ E-ISSN: 2746-8607 \\ http://jurnal.unipasby.ac.id/index.php/jsbr
}

\title{
Pengaruh Leverage dan Likuiditas secara parsial berpengaruh terhadap Konservatisme Akuntansi
}

Ujian hipotesis dua $(\mathrm{H} 2)$ yakni uji t didapatkan variabel leverage mempunyai nilai thitung sejumlah $0,921<2,920$ dengan tingkat signifikansi $0,381>0,05$ sehingga terbukti tidak ada pengaruh secara signifikan antara leverage terhadap conservatism akuntansi. Karenanya hipotesis yang menyatakan leverage berpengaruh positif terhadap konservatisme akuntansi ditolak.

\section{IMPLIKASI}

Implikasi penelitian ialah konservatisme akuntansi perlu diperhatikan oleh perusahaan agar melaporkan nilai-nilai dalam laporan keuangan. Laporan yang konservatif akan membuat investor atau kreditor lebih memperhatikan setiap laporan keuangan yang dipublikasi oleh perusahaan.

\section{KETERBATASAN PENELITIAN}

Terdapat adanya keterbatasan antara lain minimnya jumlah sampel penelitian,sehingga diharapkan peneliti dapat menambah objek penelitian dengan memakai semua perusahaan yang terdaftar di Bursa Efek Indonesia, peneliti diharapkan menguji dengan menggunakan variabel lain.

\section{DAFTAR RUJUKAN}

Belkaoui, A.R, 2006, Accounting Theory: Teori Akuntansi. Edisi Kelima. Jakarta: Salemba Empat.

Enni Savitri, 2016,konservatisme akuntansi.1 (1). Pustaka sahila Yogyakarta, Yogyakarta.isbn 60269503-3-8.

Khusnah Asmaul,2019.Pengaruh Kepemilikan Manajerial, Leverage, dan Financial Distress Terhadap Konservatisme Akuntansi. Skripsi . Universitas Muhammadiyah Gresik. 
Journal of Sustainability Business Research (JSBR)

Vol-1,Issue-1,Desember (JSBR)

E-ISSN: 2746-8607

http://jurnal.unipasby.ac.id/index.php/jsbr 